\title{
Anemia and H7N9 Bird Flu: A Forgotten Problem
}

\author{
Somsri Wiwanitkit • Viroj Wiwanitkit
}

Received: 5 September 2013/Accepted: 24 October 2013/Published online: 8 November 2013

(C) Indian Society of Haematology \& Transfusion Medicine 2013

Sir, the problem of emerging H7N9 bird flu is an important world problem. Focusing on the clinical presentation, there are various manifestations as well as laboratory parameter disorder [1]. Focusing on hematological parameters, an important forgotten finding is anemia. Based on the present knowledge, there is still no specific report considering anemia in the patients with H7N9 bird flu. In fact, anemia is identified as an important clinical finding in the previous well-known emerging H5N1 bird flu [2]. Focusing on the present H7N9 bird flu, based on 7 patients with complete data on hemoglobin $(\mathrm{Hb}<12 \mathrm{~g} / \mathrm{dL})$ in the reports by Chen et al. [3] and Jie et al. [4], the prevalence of anemia can be detected at $42.9 \%(3 / 7)$, which seems to be very high. However, focusing on anemic cases, no cases had hemoglobin level less than $10 \mathrm{~g} / \mathrm{dL}$. Of interest, all cases with identified anemia ended up with death and no case with no anemia died.

Based on these data, it might seem that the anemia is a common problem in H7N9 bird flu and might have some clinical relationship to poor outcome. Nevertheless, the detected anemia might be an underlying disease of the infected cases or might be a problem induced by viral infection. Further study on the pathobiology of anemia and its clinical importance in H7N9 bird flu is warranted.

\section{References}

1. Wiwanitkit V (2013) H7N9 influenza-the laboratory presentations: a letter to editor. Asian Pac J Trop Biomed 3(7):584-585

2. Wiwanitkit V (2005) Anemia in the recent reported cases of bird flu infection in Thailand and Vietnam. J Infect 51(3):259

3. Chen Y, Liang W, Yang S, Wu N, Gao H, Sheng J, Yao H, Wo J, Fang Q, Cui D, Li Y, Yao X, Zhang Y, Wu H, Zheng S, Diao H, Xia S, Zhang Y, Chan KH, Tsoi HW, Teng JL, Song W, Wang P, Lau SY, Zheng M, Chan JF, To KK, Chen H, Li L, Yuen KY (2013) Human infections with the emerging avian influenza A H7N9 virus from wet market poultry: clinical analysis and characterisation of viral genome. Lancet 381(9881):1916-1925

4. Jie Z, Xie J, He Z, Song Y, Hu Y, Li F, Shen Y, Shi J, He Y, Huang Q, Gu Y, Bai C (2013) Family outbreak of severe pneumonia induced by H7N9 infection. Am J Respir Crit Care Med 188(1):114-115

\author{
S. Wiwanitkit $(\bowtie)$ \\ Wiwanitkit House, Bangkhae, Bangkok, Thailand \\ e-mail: somsriwiwan@hotmail.com \\ V. Wiwanitkit \\ Hainan Medical University, Haikou, China \\ e-mail:wviroj@yahoo.com

\section{Wiwanitkit} \\ Faculty of Medicine, University of Nis, Nis, Serbia \\ V. Wiwanitkit \\ Joseph Ayo Babalola University, Ikeji-Arakeji, Nigeria
}

